Portland State University

PDXScholar

1974

\title{
Occupational Prestige Among Chinese in the San Francisco Area
}

Linda Fong

Portland State University

Follow this and additional works at: https://pdxscholar.library.pdx.edu/open_access_etds

Part of the Social Work Commons

Let us know how access to this document benefits you.

Recommended Citation

Fong, Linda, "Occupational Prestige Among Chinese in the San Francisco Area" (1974). Dissertations and Theses. Paper 1713.

https://doi.org/10.15760/etd.1712

This Thesis is brought to you for free and open access. It has been accepted for inclusion in Dissertations and Theses by an authorized administrator of PDXScholar. Please contact us if we can make this document more accessible: pdxscholar@pdx.edu. 
LD 4349

- A84

1974

. F 6

OCCUPATIONAL PRESTIGE AMONG

CHINESE IN THE SAN FRANCISCO AREA

by

IINDA FONG

A report submitted in partial fulfillment of the requirements for the degree of

MASTER OP

SOCIAL WORK

Portland State University

1974 
TABLE OF CONTENTS

PAGE

LIST OF TABLES $\ldots \ldots \ldots \ldots \ldots \ldots \ldots \ldots \ldots \ldots \ldots \ldots \ldots \ldots$

CHAPTER

I. INTRODUCTION.................... 1

Definitions................... 3

II. REVIEW OF IITERATURE............... 15

III. METHOD OF STUDY ................... 22

Hypothests..................... 22

Source of Data and Collectlon....... 22

Changes from Pretest............. 25

Ahalys1s of Returns.............. 25

IV. DATA ANALYSIS................... 26

General Characteristics of

Respondents.................. 26

Respondent Att1tudes Concerning

Chinese Pract1ces............. 30

Lack of Parameters............... 35

Data Testing, Hypothes1s, and

Results.................... 38

v. SUMMARY AND RECOMMENDATIONS.......... 42

Summary and Implications......... 42

Discussion.................. 44

Recommendations................ 48 


\section{IIST OF TABLES}

TABLE

PAGE

A. Demograph1c Character1stics of Respondents................... 27

B. Overview of Respondent Attitudes Concerning Chinese Practices......... 30

I. Chi Squares for Sorting of Base Data... 
CHAPTER I

\section{INTRODUCTION}

The alm of our study is to understand Chinese attitudes towards occupational prestige in order to be able to counsel famliles and youth in career goals, and to maximize potentials and enhance life chances. Our porpose 1s to arrive f1rst at an occupational rankIng or rating since there is none to be found in the I1terature/on which more spec1fic studies could later be compared. Another purpose is to see whether there were major differences between traditional and modern Chinese, and find what tralts were assoclated with differences in attitudes and expectations, as further Indices of approprlate approaches to soclal services. The Nees in their book, Longtime Callforn', speak of the need to study Chinese people in their iffe situation:

We found that the people (In Chinatown) were generally encouraging and positive about the prospect of a community study done by a fellow American Chinese. They agreed it had been necessary to return to Chinatown for a longer perlod of work in order to deal responsibly with its complicated soclety and past. Many expressed a sense that they had been victimized by a long history of misunderstand1ng, oversimplification, and distortion of the American Chinese community and those who lived outs1de. They felt there was an urgent need for clear analys1s which would dispel destruct1ve stereotypes of Chinatown. Every ane, from 
the "establishment" to the "radical," stressed that the book could make its greatest contribution by being objective. 1

The original intent was to gain a random sample of the Chinese population in San Francisco. But due to fallure to obtain the cooperation of the newspaper editors of the Chinese community, a systematic random sample was taken from the San Francisco phone book. A sample of four hundred names was drawn and questionnalres were sent to three hundred elghty people. See Appendix A for questlonnalre. The return was poor, coming to only flfty. Upon attempting to find parameters for our study to see if our study was representative though small, none could be found. Consequently, our rindings are not representative of the Chinese population in San Francisco, only of some, namely our sample.

The rationale for attaining the sample thus was first getting the total number of Chinese residents who had I1sted phones in the San Francisco area. Those 11sted in Daly C1ty, Brisbane or Colma were purposely excluded, as they were not a representative part of the San Franc1sco population. After obtaining a total number 13,196 and dividing 1 t by 500 , the quotient 26 was obtalned. Thus, the questionnalre was sent to every twenty-s1xth name on the 11st. The 
systematic sample did not account for an equal number of women.

Definitions

Traditionalism:

The traditionallst has strongly internalized Chinese values. There $1 \mathrm{~s}$ an attempt to be a 'good' son or daughter. Primary allegiance is to the family into which he was born. Selfworth and -esteem are defined by his ablilty to succeed in terms of high educational achlevement, occupational status, etc. W1th success, he feels respectable in American soclety; he has brought honor to the famlly name and has accomplished this, all as a minority member. ${ }^{2}$

Despite his attempt to confine his social ilfe to the Chinese subculture, he is unable to fully 1solate himself from members of the host soclety. Learned patterns of obedience and conformity are transferred to the interactions with them... Role expectations in the Chinese family are well-defined and structured, he (trad.) may find 1t difficult to Interact with Caucasians, who are often behaving under different expectations... frequent ly... diametrically opposed... As for Institutional rac1sm, the traditionalist is often less aware or concerned, since he believes he can overcome obstacles if he works hard enough. 3

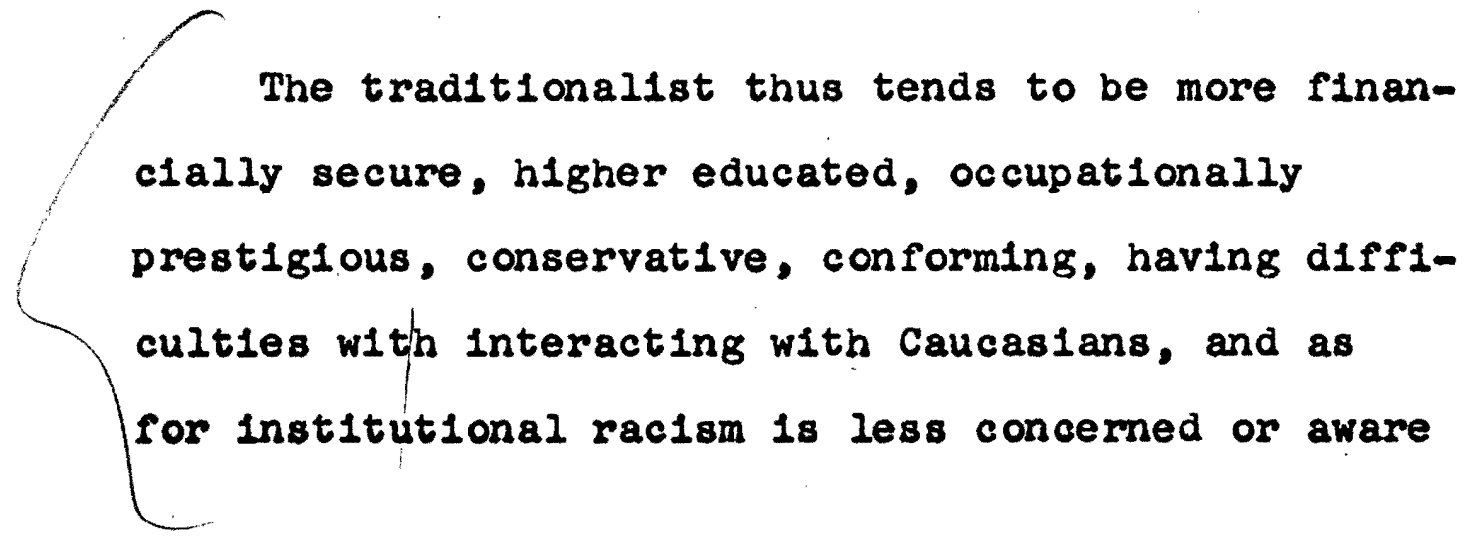


For an operational definition of traditionalism and modernism there was use of several criteria in terms of responses to the questionnalre used in the study: language and usage of the two main Chinese dialects, diet, traditional Chinese practices, att1tudes towards dating and marriage practices. For the purposes of our study, the criteria set for a traditionalist was that he celebrate Chinese New Year's, belleved that father or grandparents should rule the home, checked "yes" or "depends" on obedience to parents on school, career, mate, belleved that boys should be encouraged to go to college, and then would say that Chinese should marry Chinese.

The Chinese modern has been described by Sue as the "Marginal" man, and the "Asian American." To quote:

The Marginal Man attempts to assimilate and acculturate into the majority soclety. Existing between the margin of two cultures, he suffers from an 1dentity cris1s... finds self worth defined in terms of acceptance by Caucasians... hostility and denial of his minority culture may cause him to turn his hostility inward and to develop a form of 'racial self-hatred.' The Aslan American tried to formulate a new Identity by integrating his past experiences with his present conditions. He shares common patterns w1th the other two... he associates with other Chinese without embarrassment as does the Traditional1st. And like the Marginal Man, he experiences some guilt for his unwlilingness to fully accept the dictates of his parents. However, the Aslan American's deflance 18 less a rejection of Chinese ways 
than an attempt to preserve certain Chinese values in the formation of a new 1dentity... complete obedience to traditional values limits his self-growth... his political and social awareness $1 \mathrm{~s}$ more fully developed... orlentation also Includes other Aslan groups as a basis for 1dent1ty... the group is extremely Important to h1m... Anyone who is percelved to threaten the Asian American group 1s, in a real sense, threatening his identity. Thus he may feel quite intolerant of the traditionalist and particularly, of the Marginal Man who wants to assimllate... may become 4 extremely militant in his reaction to racism. 4

The Modern thus tends to be less sure of his 1dentity and at tempts to integrate 1t through assimilation into the white culture or to form a new 1dentity, associates with other Chinese, feels gullty for not being "obedient" or "good" toward his parents, struggles with Chinese values, is more socially and politically aware, and threatened regarding identity by any attack on his Aslan group.

Operationally defined, the Modern would respond to the questionnaire 1tems by saying that mother and father ruled the home or that there should be a cansensus of family opinion, "no" to obedience to parents regarding $8 \mathrm{chool}$, career, mate; girls should be encouraged to go to school or answered w1th "depends....," and would say that Chinese should marry any of the categorles 11sted other than "ChInese." Th1s would mean "other orlentals," "whites," and "anyone." 
Demograph1c Traits

The demographic tralts of some of the San Fran01000 Ohinese are now stated. The following data 18 gathered from Chinatown 2970 Census: Population and Housing Summary Analysis. It is significant to note that the area of this study included only 56.6 percent of the total Chinese population of San Francisco. The area studied Included a core area consisting of census tracts 113, 114, and 118; a residential area of tracts $6,7,8,10$, and 15 ; and then an expanded area of tract numbers $3,4,9,11$, and 12 .

Population:

Population density is extremely high as compared to the city's average and to other neighborhoods in the c1ty. Density reached a high of 228.1 persons per net acre, 7.2 t1mes greater than the c1ty's average of 31.7 persons.

Wh1 a high concentration of Chinese and other orientals was evident in the "core" area ( 88.5 percent (hinese), a continuing trend of migration to adjacent areas boosted the concentration of Chinese and other orientals in the residential area to 73.7 percent, and the expanded area to 56.6 percent. 
In 1970, there were 435,062 Chinese in the United States. Th1s was an increase of 83.3 percent over the total in 1960. San Frano1sco was second to New York In ChInese population. Although San Francisco contains 13.5 percent $(58,696)$ of the total Chinese population In the United States, New York has 15.9 percent. However, San Franc1sco has the h1ghest percentage of Chinese population in relation to 1 ts total population of any c1ty in the nation.

Nationally and locally, the Increase in Chinese population in the last decade was attributed to 1mmigration rather than natural increase.

Youths, young adults 15 to 24 years $01 d$, and elderly persons of 65 years and over are the only groups that experlenced 1ncrease. In 1970, there were 9,854 people between the ages of 15 and 24 in Chinatown, an increase of 84 percent over 1960 population f1gures. This segment accounts for 17.6 percent of the total Chinatown population, and 7.9 percent of the c1ty's age group. Elderly people in 1970 numbered 8,068, an Increase of 16.5 percent over 1960.

The median age for Chinese in the expanded area is 36.0 - for the c1ty 1t 1s 35.7. Median age for the nonwh1te population in the expanded area 18 33.5, while that in the ofty 1826.9 . 
Increase in age group 15 to 24 is attributed to the postwar baby boom, and Immigration of families with chlldren this age; the increase in elderly persons 1s attributed to better medical service, thus longer survival rates. Considerable numbers of elderly women Immigrated to the United States during the ten years to rejoin their husbands. Th1s, plus the postwar baby boom, has made the sex ratio a little more equal.

In 1960, there were 7 percent more males than females. This difference decreased to 6 percent in 1970. Increases in young females aged 15 to 25 years as well as female sentor c1t1zens aged 65 and over were responsible for this change.

Fam1ly population increased by 5.8 percent during the decade: from 36,780 in 1960 to 38,905 in 1970. The number of familles increased by 2.4 percent; the average family size increased slightly from 3.3 in 1960 to 3.4 in 1970 .

Forty-two point elght percent of the famllies had chlldren under 18 years old. The average number of ch1ldren under 18 per family ranged from a high of 2.3 per family in the core Chinatown to 1.9 in the outskirts. 
Households:

From 1960 to 1970, the number of households decreased by 2.0 percent, that is, from 26,110 to 25,575. Th1s decrease of households was mainly caused by the decrease of primary individuals which, together with heads of famllies constituted the total number of households. The decrease of primary individuals, a loss of 5.4 percent from 1960 , is contrary to the general increase not on $1 y$ in San Francisco, but in the Bay Area as well.

Housing:

Since 1960 , there has been a 5 percent decrease in the number of houses in the chinatown area. The housing units in Chinatown which are predominantly renter-ocoupled have lower vacancy rates than the clty as a whole, and there are fewer of them. In the Chinatown "core" area, more than two-th1rds of the housing stock consists of units of two rooms or less. In the Chinatown expanded area, 13.4 percent of the total housing stock is overcrowded. One quarter of these are located In the "core" area - this level of concentration was three and a half times higher than the olty's proportion of overcrowded units. Overcrowded units 
were 52.2 percent more than in 1960. Th1s rate of Increase was $81 x$ times greater than the city's average.

Quite a number of these housing units were found deflclent in both plumbing and kitchen facilities. The substandard housing accounted for 26 percent of the clty's total. The highest concentration, amountIng to 43.7 percent, was in the Chinatown "core" area.5

Communal k1tchens and bathrooms are a way of 11 fe in these bulldings. The electric wiring systems are antiquated, and many of the windows face into alleys or brick walls 80 that rooms are completely deprived of natural light.

\section{Health:}

Many of the bachelors, who st1ll have problems with their immigration status, fear seeking medical assistance from the government health agencies and for years have had absolutely no medical attention. They suffer from general malnutrition, trachoma, tuberculosis, alcoholism, and depression. Unt1l the estabilshment in 1970 of the Northeast Medical Services, health facilities in Chinatown were extremely limited. For a population of over 40,000 people, there was one hospltal with 60 beds. In 1969, it was estimated that there were at least ten thousand people in the community who could not afford medical care.

To these medical indigents, only one outpatient clinic was avallable. It included a tuberculosis clinic, baby, dental, Immunization, and public health 
nursing service. In a year, the clinlc provided care for approximately fifteen hundred people. In this area, there is one dentist per 2,500 patients. In 1969, with only two Chinese-speaking psychlatrists in San Franc1sco, it was estimated that twenty hours of direct service was avallable to the poor and non-English-speaking. Chinatown resldents per week. The highest tuberculosis rate and sufcide. rate in the nation are still held by Chinatown at the present time.

Education:

Unt1l school busing began in 1971, the majority of Chinatown chlidren attended the three public grammar schools whlch had enroliments which were ninety-flve percent Chinese. In the evening, they study Chinese language in one of the twelve Chinese schools in the community. These number about onethird of the Chinese elementary students.

Recently there has been a serlous confrontation between Chinese parents and the San Francisco School Board. Leaders of the communtty have crlticlzed the Board for not being sensitive to the community. At Gallleo H1gh School, s1xty-one percent of the teaching staff 18 white. All principals of the predominantly Chinese schools are wh1te. The Board has been unwillIng to make adequate preparations to accomodate the 
large Influx of Immlgrant youths from Hong Kong, most of whom have sertous language problems.

Worship:

The most numerous places of worship in Chinatown are the Christian churches. The Buddhist Church draws a large congregation. The Jeng Sen Buddhist and Ta01st Assoolation are open dally. Remnants of ancestor worsh1p are visible in many homes.

\section{Conclusions}

Remembering that the Census study was limited to only 56 percent of the San Franc1sco Chinese and how 1t explored the parameters of the "Chinatown" area, we make these generalizations.

Population density is very high as compared to the c1ty. There is a continuing trend of Chinese to move to adjacent areas in Chinatown. There are almost twice the number of Chinese in the United States as there were in 1960, San Francisco having the highest percentage in relation to the total population. Th1s 18 due to immigration and natural increase. Though there has been a large increase in the numbers of young people (15-24) and old ( 65 plus), the median age has remalned close to the clty's median of 35.7 . There was a b1g decrease in proportion of men from 
1960 to 1970. The number and s1ze of familles increased slightly whlle there were fewer places to I1ve - those avallable beling substandard. The health of much of the population 18 poor and avaliable services few. Most Chinese chlldren attend one of the three schools in the Chinatown area - of which they make up 95 percent of the enrollment. There 18 a larger number of Protestant churches than of the traditional Buddhist or Tao1st churches.

These are some parameters of approximately half of the population of our study. They are necessary to examine and to make comparisons with the demograph1c tralts of the population of our sample. 
CHAPTER NOTES

$I_{V 10 t o r} G$. Nee and Bret de Bary Nee, fongtime Callforn', Pantheon Books, New York, 1972, 73, p. $x \bar{x}-x \times x^{\prime}$.

${ }^{2}$ Stanley Sue and Derald Wing Sue, "ChineseAmerlcan Personality and Mental Health," As 1anAmerlcans' Psychological. Perspectives, ScIc ace and Behavior Books, Inc., Bentomond, Californ1 , 1973, P. 113.

I Ib1d. . p. 114.

4Ib1d., pp. 115-120.

5 San Franc1sco Department of C1ty Planning, ChInat own 1970 Census: Population and Housing Summary and Analysis, August 1972, pp. 3-6.

6Nee, op. c1t., xx111. 
CHAPTER II

REVIEW OF LITERATURE

Little pertinent information has been published with specif1c regard to our research project. There has been much written regarding occupational ranking of different groups in the white majority of America, but not much regarding minority groups - specif1cally As1an-Americans.

To shed some light on how Chinese feel about tradition, modern1sm, and occupations, the present paper is an Inftial attempt at an analys1s of San Francisco's Chinese within the limltation of our research sample.

The I1terature of how ChInese feel about occupations w1ll be examined first, then a broader focus of other comparative Asian studies, concluded by some studies that may reflect the future of occupational aspirations for the Chinese.

The following contrasting statements, which appeared in the same perlodical, reflect the occupational status of Chinese in Amerlca.

One such minority, the nation's 300,000 Chinese Americans, is winning wealth and respect by dint of 1 ts own hard work. 1 
Not all Chinese Amerlcans are rich. Many, especially recent arrivals from Hong Kong, are poor and cannot speak English. But the large majority are moving ahead by applying the traditional virtues of hard work, thrift and morality. ${ }^{2}$

Regarding kinds of occupational successes,

Chinese-American males have exper1enced many successes in American society. They have proven themselves as scholars in our education system, enterprising. entrepreneurs in the1r business ventures, and professionals. 3

In an attempt to gather information of normative att1tudes of how ChInese-Amerlcans view occupations, the researcher looked for common threads in the varlous prestiglous occupations of the Chinese.

In a study made by Sue and K1rk of the entlre entering Preshman class of the University of Callfornia at Berkeley, it was found that Chinese-Americans preferred concrete and practlcal approaches to $11 \mathrm{fe}$.

Chinese males tended to avold the social sclences, business contact occupations, and verbal-lingulstic fields; they showed predominate interests in the physical and blological sclences. Chinese-Amerlcan females were much more domestically orlented than other females. The results show intraconsistency. If Chinese are Inhibited, soclally withdrawn, and lower in verbal sk11ls (but h1gher in quant1tative ab1lities), then they, understandably, have interests in flelds minimizing interpersonal interactions. 4 
Th1s reflects the high number of Chinese males who enter scient1flc flelds such as pharmacy, engineerIng, mathemat1cs rather than becoming teachers, social workers, and psychologists.

It 18 important to note that the lower verbal ablilty found in the Sue/K1rk study could be partially accounted for by a bllingual background. Noting that all the tests administered were in English, cultural blas in testing was not accounted for.

One of the common threads of the pursuit in the physlcal and blological science is high academic achlevement. DeVos and Abbott found that educational achlevement is consistently valued above other types of achlevement in Chinese families: Consequently, college and higher education are the ratural course of events. Th1s achlevement, espectally for Chinese males, is prior to any other achievement.

Education has been utillzed by the ChInese to move Into hlgher income and soc1al classes. What has been found by Eckland is true for the Chinese.

Without a college degree, academic achievement is signiflcantly affected by class origins. Thus the effects of academic ablilty operate solely within the context of the social system, with the high class origin operating as a buffer against downward moblilty of sons of nonmanual workers who drop out. These findings put into question the conception that the university functions effectively to sort 
and allocate talent into the most appropriate occupational statuses in our social structure. 7

Shifting to a broader focus, in an attempt to find any correlating studies between tradition and occupations, intergenerational studies of occupations were examined. Again there was little, howbe1t the evidence was significant.

Mowsisean, Heath, and Rothney found that in comparing the occupational preferences of bright, white sons and fathers in Wisconsin that:

...two-th1rds of the 147 boys tended to make choices at the professional level early in high 8 chool and to maintain them. The father population consisted of 5 percent unskilled, and 71 percent non-professional. Children or professional fathers tended to make choices at the same level, whereas those of nonprofessional fathers tended to choose different levels, thus refuting the results of other studies. Preferences of those whose cholces changed two $8^{r}$ more times also tended towards professions. 8

Bacol found the following about Phllippine father and sons:

Sons have a propensity to inherit the social stratum of fathers. A substantial number of sons in any occupational group all came from farm orlgins. By and large, the top-ranking and low ranking occupations are relatively closed. Contrariwlse the lower professions and the clerical strata are relatively open. Vertical moblilty 18 characteristically a short distance. A son's education is more important than his father's status in 
determining the son's occupational success. In the case of sons coming from higher soclal orlgins, occupational success is positively recelved with education. In the oase of 8 ons coming from lower social orlgins, social origin diminishes the importance of education as a vehicle for moblilty.9

Marsh found in h1s study of occupational prest1ge hlerarchy that the Talwanese were similar to other socleties. He made his comparison with the hierarchles of Amer1cans, Danes, Japanese, P1lipinos and others. 10

Another study that was made in Braz1l supporta this theory of common hierarchles, olting the fact that urban living plus industriallzation were key factors in producing occupational hierarchles. 11

Regarding the employment ploture for the Chinese Amerlcans in the future, Chinese need not be ashamed for being reserved or emotionally inhibited. These are h1ghly valued characteristics of Chinese tradition - and did serve a purpose of self-protection at an earlier period In United States history. Concern now needs to be focused on the functional values of these traits under the present clrcumstances. Traits must now be adopted for attaining proclaimed goals. 


\section{Conclusions:}

Chinese-Amerlcans prefer a more concrete and praot10al approaoh to 11fe. Due to less English verbal fac1lity, their occupational interests are in flelds that minimize interpersonal interactions. They show predominate interests in the physical and blologlcal rlelds, though capable in any chosen fleld. 
CHAPTER NOTES

I"Success Story of One Minority Group in the U. S.," U. S. News and World Report, December 26, 1966, p. 73 .

$$
2 \text { Ib1d., p. } 74 .
$$

3 Beulah Ong Kwah, "Occupational status of the American Born Chinese College Graduate," Doctoral Dissertation, Univers1ty of Ch1cago, 1947, p. 113.

${ }^{4}$ D. W. Sue and B. A. K1rk, "Psycholog1cal Characteristics of Chinese-American Students," Journal of Counseliling Psychology, 1972.

5G. A. DeVos and $K$,Abbott, "The Chinese Family In San Franc1sco," MSW D1ssertation, Un1versity of Callfornia, Berkeley, 1966.

6 Ib1d.

7B. K. Eckland, "Academ1c Ab1lity, H1gher Education, and Occupational Mob1lity," American Sociological Review, 1965.

$8_{R}$. Mowsisean, B. R. G. Heath, and J. W. M. Rothney, "Super1 or Students' Occupat1onal Preferences and their Father's Occupation," Personnel and Guldance Journal, 1966, pp. 238-42.

9Melinda M. Bacol, "Intergenerational Mob1lity In the Ph1llppines," Philippine Soc10logical Review, 1971, pp. 3-4.

10Peter Marsh, "The Explanation of Occupational Prest1ge," Soc1al Forces, December 1971.

1l"Variations in Occupational Prestige Hierarchles: Braz1lian Data," American Journal of Soc10logy, March 1972 , pp. 941-956. 
CHAPIER III

METHOD OF STUDY

\section{Hypothesis}

There would be a difference between traditional1st and modernists and it is unknown wh1ch way the differences would go. The null hypothesis is that there 18 no difference between the way traditionalists and modernists scored or ranked these occupations.

Source of Data and Collection

Orlginally, 380 questionnalres were to be sent out to obtain a response of at least 297 needed for the 5 percent confidence level. These were to be taken from newspaper subscription 11sts, from left to right wing in orientations, affording contrast groups, and the best 11st avaliable. Since some papers did not w1sh to cooperate, the sample was drawn from the telephone directory by taking every twenty-sixth Chinese name that was clearly Chinese. Besides the usual blases of such a sample method, the respondent was not fixed in each household and might be expected to reflect $s$ ome status or educational bias. 
Description of Questionnaire

The completed questionnalre contained six pages and twelve pages, an English and ChInese version respectively. A head letter was written in English and chinese. The respondents could then respond to the language they knew best.

The head letter introduced the researcher to the respondents, glving brief background information about the researcher and the research project. I also told the respondents that I had obtained their names from the various newspaper subscription 11sts. (At this polnt, there was no time to alter this statement to the San Franc1sco phone directory.) A deadilne of one week following date of malling was stated. The researcher stressed the confidentiality of the responses, saying that the findings would be reported only in terms of groups. Instruction was noted so that the respondent would f1ll out the English or Chinese questionnalre appropriate to them. I closed the letter saylng that a stamped, self-addressed envelope was enclosed for their usage and told them to respond freely with their comments.

F1fty-81x persons responded and returned the questionnalres. Of the f1fty-six responses, six were incomplete; their responses were not tabulated. 
As will be seen in the following chapter, the sample is probably blased in the direction of higher education and income. Projections to the general Chlnowe oommunity must be oarefulizy made.

As the respondents returned the questionnalres, the responses were tabulated and recorded.

\section{Variables Measured}

The dependent variables measured were seventynine different occupations. These included the high, medium, and low occupations of various flelds: business, medicine, education, artist1c, and the helpling profess1ons. The Independent variables measured were: head of household or relationship to head, occupation, sex, age, marital status, income, place of birth, education, Chinese language usage and Pluency, Western and Chinese dietary practices, att1tudes towards Chinese values, Chinese practices, parental and chlldhood relationships, and dating and marriage attitudes.

Occupations were to be ranked on a scale of $1-100$ based on how the person regarded the occupation - and not particular people in them. H1gh, medium, and low occupations were listed in the following categorles: business, education, medicine, the helping professions, skilled and unsk1lled laborers, clerical, and creative. 
Changes from Pretest

The questionnalre was pretested on thirty Chinese at the Chinewe Baptist Churoh in Portlend, Oregon or whom nine responded. Small changes in wording resulted.

Analysis of Returns

Ch1 square, T, rank correlat1ons were used as tests of slgniflcance and descriptions, $r$ and regresslons if indicated. A random sample of selected occupational groups from the returns was taken for ayalys18, and not the whole returns. A sample of twenty-four occupations were drawn from the total of seventy-nine. Pour occupations were randomly chosen from the flelds of business, medicine, education, the helping professions, skilled laborer and unskilled laborer categorles. Each category of occupations was drawn at random from a hat. The rationale for th1s sampling and analysis was to be able to meet the deadline date of the report. 


\section{CHAPTER IV}

DATA ANALYSIS

Description and analysis of responses for the study are presented in three parts: the f1rst part describes some of the general characteristics of the "returns" population; the second part w1ll speak of the lack of parameters; and the third part contains data testing, results, and discussion.

General Characteristics of Respondents

Demographic characteristics of the respondents are described in Table A. The flfty respondents described here are all of Chinese herltage, they range from age seventeen to s1xty-e1ght, with a mean age of 37.1. Age was reported for all f1fty of the respondents. The respondents hold various occupations and represent households which vary in size from a oneperson household to a seven-person household.

See Appendix A for the English questionnalre. The Chinese version of the questionnalre 18 avallable from the author for research purposes. 
TABLE A

DEMOGRAPHIC CHARACTERISTICS

OF RESPONDENTS

\section{RESPONDENT}

Head of Household

Other

$62 \%$

$38 \%$

$\underline{\text { SEX }}$

Male

$68 \%$

Pemale

$32 \%$

MARITAL STATUS

Married

$52 \%$

Widowed

1 person

Single

$41 \%$

Divorced

2 persons

HOUSEHOLD INCOME (2972)

$\$$

$0-\$ 1,999$

4 persons

$\$ 2,000-\$ 4,999$

$1 \%$

$\$ 5,000-\$ 9,999$

$20 \%$

$\$ 10,000-\$ 14,999$

$26 \%$

$\$ 15,000-\$ 19,999$

$16 \%$

$\$ 20,000-\$ 25,999$

$14 \%$

$\$ 26,000$ and up

1 person 
TABLE A - Continued

\section{COUNTRY OF BIRTH}

China

(Including mainland China,

$51 \%$

Talwan, Macao, and Hong Kong territories)

U.S.A.

$38 \%$

Other

5 persons

PLACE OF EDUCATION

AII U.S.A.

All Ching

Both

Grade School

High School

Some College

College Graduation

Postgraduate

Masters

Doctorate

Other
$62 \%$

4 persons

$28 \%$

EDUCATION 
TABLE A - Continued

\section{LANOUAOE FLUENCX}

Cantonese

Well

Average $\quad 25 \%$

Somewhat $22 \%$

None

\section{Mandarin}

Well $10 \%$

Average $\quad 14 \%$

Somewhat $25 \%$

None

$14 \%$

\section{LANGUAGE READ}

Engl1sh

$41 \%$

Both English \& Chinese

$59 \%$

LANGUAGE WRITTEN

Eng118h

418

Both English \& ChInese $59 \% *$

"Rounded off to nearest percent

Respondent Att1tudes Concerning Chinese Pract1ces

An overview of respondent attitudes concerning various Chinese practices is given in Table B. 
TABLE B

OVERVIEW OF RESPONDENT ATTITUDES

CONCERNING CHINESE PRACTICES

\section{CHINESE LANGUAGE ATTITUDE}

Yes (Chinese should learn Chinese) 90\%

No $0 \%$

Not Sure 3 people

DIETARY PRACTICES

Western D1shes

Chinese D1shes

Eat Often

$24 \%$

Eat Often

$90 \%$

Eat Sometimes 60\%:

Eat Somet1mes

2 persons

Eat Seldom

4 persons Eat Seldom

1 person

CHINESE VALUES

H1ghly Sympathet1c

$37 \%$

Sympathet1c

$22 \%$

Neutral

$16 \%$

Unsympathetic

2 persons

H1ghly Unsympathet1c

1 person

Myxed

$17 \%$

MEMBERSHIP IN TONQ/CHINESE ASSOCIATIONS

$\underline{\text { Yes }}$

4 persons

No

$90 \%$ 
TABLE B - Cont1nued

\section{HERBALIST}

Yes

No

6 persons

Perhaps $56 \%$

RELIGION

Buddhist

3 persons

Protestants

$23 \%$

Catholics

$12 \%$

Other

$57 \%$

CELEBRATE CHINESE NEW YEAR'S

$\underline{\text { Yes }}$

$90 \%$

No

5 persons

CELEBRATE CHINESE INDEPENDENCE DAY

Yes

$29 \%$

No

718

FAMILY RULER

Father

28\% Grandparents

4 persons

Father \& Mother $61 \%$ Other

1 person 
TABLE B - Continued

\section{PARENTAL OBEDIENCE}

In Sohool Cho1ce

In Mate Cho1ce

Yes and Depends 78\% Yes and Depends $55 \%$

No $22 \%$. No $45 \%$

In Career Cholce

Yes and Depends. $54 \%$

No $46 \%$

BOY TO COLLEAE

Strongly Agree 3 persons Disagree $\quad 38 \%$

Agree

4 persons Strongly

D1sagree $27 \%$

Neutral

$25 \%$

Mixed

2 persons

BOY/AIRL TO SCHOOL CHOICE

Boy

81\%

Girl

3 persons

\begin{tabular}{l|ccl} 
& \multicolumn{2}{c}{ CHINESE SHOULD DATE } \\
\cline { 2 - 4 } Chinese & $20 \%$ & Others & 2 persons \\
Also Orientals & $11 \%$ & Anyone & $51 \%$
\end{tabular}

ChInese, Orientals,

Wh1tes 2 persons 
TABLE B - Continued

\section{CHINESE SHOULD NOT DATE}

\begin{tabular}{|c|c|c|c|}
\hline Whites \& Others & $26 \%$ & $\frac{\text { Orientals \& }}{\text { Wh1tes }}$ & 1 person \\
\hline $\begin{array}{l}\text { (4l, of which were } \\
\text { specified as "Blacks") }\end{array}$ & & Whites & 3 pe \\
\hline
\end{tabular}

CHINESE SHOULD MARRY

Chinese

Anyone

Chinese \& Orientals 15\%

\section{CHINESE SHOULD NOT MARRY}

Whites \& Others
Others
(47\% of wh1ch were
specified as "Blacks")

Orientals \& Whites
$18 \%$

$78 \%$

Orientals 2 persons

Whites

1 person 
Summing up the majority *esponses regarding general characteristics of the respondents, most respondents in this descriptive study are heads of households. There are significantly more male than female respondents, and sllghtly more married than unmarried ones. The median family income of our study was $\$ 12,500$, Sllghtly over half of the respondents were born In the United States, followed by onethird born in ChIna. Most respondents were educated In the United States, with approximately a third educated in both countries. The majority of respondends have had elther some college or have graduated from college. A majorlty of our sample speak Cantonese elther "well" or "average;" sllghtly under a half spoke Mandarin e1ther "somewhat" or "average." Most of the respondents could read and write in both ChInese and Engllsh.

A great majorlty of our group maintained that Chinese young people should learn the Chinese language. A great majority ate Chlnese food often; just under two-th1rds ate Westem dishes somet1mes. Slightly over the majority were elther highly sympathet1c or sympathet1c to Chinese values. A large majorlty did

\footnotetext{
"The term "majority" 1s used to mean fifth percent or more.
} 
not belong to a Tong or other Chinese association. Slightly over a half sald they might go to a herbalist. A majority responded to "Other" in the religlous category, sald "yes" to celebrating Chinese New Year's, but d1d not celebrate ChInese Independence Day. The majority sald that father and mother should rule the home. A majorlty agreed or sald."depends" when asked whether children should obey their parents regarding schooling, career, or choosing a mate: Most disagreed that only boys should be encouraged to go to college; yet if given an opportunity to send only a son or a daughter, a large majority sald the boy should go. A majority sald that Chinese should date anyone they w1shed; yet reported that ChInese should not date "others" - half of whlch were specifled as Blacks. A majority replied that Chinese should marry Chinese and or Orientals and sald that they should not marry "others," (again, half of whlch were specifled as Blacks).

\section{Lack of Parameters}

Lack of parameters made it impossible to compare our demograph1c data to make any signiflcant conclusive statements pertinent to sampling or signiflcance in f1ndings. The pertinent study, "Chinatom 1970 Census: 
Population and Housing Summary and Analys1s," surveyed only 56.5 percent of the Chinese in San Franc1sco non-randomly. Even if the data were compared with this study, the comparison would be pertinent only to slightly over a half of the entire population. This is hardly adequate to represent the general demograph1e data of the entire population of the Chinese in San Francisco.

Consequently, significant parameters such as number and population by age, race density; median ages, Inoomes; and averages of persons in households and famlly are not to be had, as well as other pertinent date.

Howbe1t, let us make use of the parameters we do have and see if there are significant findings. According to the census study, the median age varied in each of the areas studied. Moving from the "core" area to the "expanded" area, the median age became lower. The "core" median age was 41.0, "resident1al" was 39.3 , and the "expanded" was 36.0 . Taking the median of these ages we have 38.7. Our study's median age 18 37.1. We differ 1.6 years. Based upon this data, we could not conclude that our sample was representative of the entire population. 1 
Secondly, according to the study there are approximately equal numbers of men and women in the areas studied, men exceeding women by a half of a percent. 2 Our study reflected a two to one rat1o of men to women. Based upon this data, we could not conclude that our sample is representative.

Finally there was no data regarding median income or education. Our study showed that for our group median income came to $\$ 12,500$ and that most had elther had some college or had graduated from college. It is interesting to note that the Sing, Chan, and Wang study done of some of Portland's Chinese reflected some similar findings. Exactly half of the study group had household incomes that ranged from $\$ 8,000$ to $\$ 16,000$ and close to two-thirds had elther some college or college graduation. In our study as in theirs, two-thirds of the "college" group were college graduates.

Other interesting points of comparison with their study are sex rat1o, countries of b1rth, and marital status. Both studies were similar in that males responded close to two to one in comparison with females. The majority of our group was borm in China, while the1r majority was born in the United States. Just over three-quarters of their group were married, while slightly over half of ours were. Our study reflected 
three and a half times more single respondents than theirs.

Their return sample was also small in comparison to the number of questionnalres sent out: 73 responses for 355 questionnalres. Our study reflected a simliar pattern: 56 responses for 380 questionnalres. The1r study. was briefer: two pages lang as compared to our $81 x$ pages. 3

Data Testing, Hypothes18 and Results

Ch1 square and rank correlations were used as tests of signiflcance and descriptions, $r$ was indicated and used. :

Our study has attempted to prove that Traditionallsts and Moderns varled in their outlook.

In order to determine if there was a significant difference between these two groups, a null hypothesis was formulated. Th1s hypothes1s stated: "There 18 no 81gniflcant difference between the Traditionalists and the Modernists."

To test this hypothes18, a Ch1 square was employed. Our study needed to compare base data with our operational definitions of Chinese traditionalism and modernism. Consequently, having categorlzed the respondents as elther traditional or modern according to the conditions stated in Chapter I, a ChI square was 
administered to see whether education, income or sex made any signifloant differences.

The results of these Ch1 squares are shown in the following table:

\section{TABLE I}

CHI SQUARES FOR SORTING OF BASE DATA

\begin{tabular}{|l|c|c|c|c|}
\hline Data Compared & D.F. & $\mathrm{X}^{2}$ & P. & Null Hypotheses \\
\hline Education & 1 & .60317 & .05 & Accepted \\
Sex & 1 & .68437 & .05 & $n$ \\
Income & 1 & 2.53225 & .05 & $n$ \\
\hline
\end{tabular}

The Ch1 square was not s1gniflcant bey ond the .05 level. W1th the Ch1 square th1s small, the null hypothesis that chance factors would be responsible for the differences was accepted. The assumption thus is that chance 18 operating in both the selection of cho1ces made by both groups. The conclusion then 18 that education, income or sex are not associated with whether Chinese persons in our group are traditional1st or modern.

A rank-difference correlation was done to see whether there 18 any association between the occupatlonal rankings of traditionalists and modernists. 
A rank correlation of .86 was measured with $N$ of 24 is significantiy different from 0 beyond the .01 level of confldence. Traditionallsts and moderns as a group tend to rank occupations similarly.

Based on Individual scorings of occupations, however, a Pearsonian $r$ ylelded a coefficlent of .106, not 81 gniffeantly different from 0 at the .05 level. Those in the sample were heterogeneous as.individuals with a wide variance on occupational scores on a 101 point scale.

Moderns tended to score occupations higher than traditionalists did, w1th a difference of 4.458 in the means over all occupations analyzed.

The conclusion of our analysis is that there is not a difference in the way traditionalists and moderns rank occupations and that the differences are not based on income, education, or sex, but are most I1kely random, or due to the reluctance of some to differentiate among speciflc occupations. The next chapter will discuss some of the 1mpl1cations of these findings. 
CHAPTER NOTES

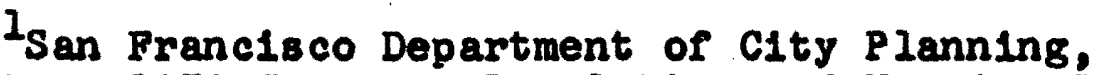
Chinatown 1970 Census: Population and Housing Summary Analys $18, p .18$.

2 Ib1d., p. 4.

3Laura Lum SIng, Wendy Po-Kow Chan, and Peter Tan-P1ng Wang, "Ch1nese At t1 tudes and Knowledge Concerning Social Services: A Survey of the Portland Chinese Community," Master's Thes1s, Port land State University, 1973, p. 33. 
CHAPTER V

SUMMARY AND RECOMMENDATIONS

Th1s chapter 18 divided Into three parts: tentative conclusions of findings and Implications for practice, critique or study, and recommendations.

Summary and Implications

As Indicated by the review of the ilterature, soclal work research is slowly being done regarding the Ch1nese in Amer1ca. Th1s research found that members of the San Franc1sco Chinese community studied are a falrly homogeneous group so far as attitudes concerning occupational rankings are concerned. It was found that there existed little difference within groups of respondents when compared according to sex, education, or household income level.

The researcher's initial opinion, unconfirmed by the research, was that Chinese are different in their responses to occupational ranking. The second impression was that the differences in response were due to being traditional or modern was not confirmed in that there was no stat1stically signiflcant difference found in the1r occupational rankings. The Moderns tended to pank the varlous occupations higher than the 
traditionafists. This confirms the impression that Traditionalists would regard occupations with less deference.

Briefly summarizing the findings, the majority of respondents ranked different occupations similarly. The majority of respondents were sympathet1c to Chinese values and practiced.Chinese customs though there was much evidence for acculturation.

Some of the Implications for soc1al work practice are discussed below.

Most of the Chinese in our sample spoke elther Cantonese or Mandarin. Professional help may be unresponsive to the needs of Chinese-Americans as there 18 a critical shortage of b1lingual therap1sts.l

Both Tom and the Sues feel that the h1gh rate of sulcide in Chinatown warrants great concern for the mental health needs of the Chinese. Low utilization of mental health faclilties may not support the latter statement as it 18 a traditional practice to keep diffloulties in the famliy. Using this natural network may lay the groundwork for community mental health. ${ }^{2}$ Present lack of parameters for research purposes makes it difflcult to do research of the Chinese population that would be generally significant. Though much research of the Chinese in America is needed, if 
one cannot compare data with parameters, the signif1cance of the data 18 of a tenuous nature.

The small sample return via questionnalre could have refleoted the conservative attitude of the Chinese to reveal their knowledge, feelings, or att1tudes. The Nees found that speaking Cantonese and interviewing are the best tools to attain the aforementioned. 3

\section{D1scussion}

A discussion of the major IImitations of this study are as follows.

The sample return 18 one limitation which must be considered here. Because of the small sample size, and the fact that return was not a random 8 ample, generallzations to larger Chinese populations must be made with reservations. However, the respondents may represent those who are most responsive in the San Francisco Chinese community in terms of occupational knowledge. A blas toward higher education and higher Income levels may be present. The small sample forced combination of categorles, so that differences were obscured. Further studies need to be conducted on a more extensive scale with larger representative samp 108. 
However, despite the limitations of sample size, 1t should be pointed out that the probab1lities computed for the associations between education, sex and possibly ipcome, versus traditional and modern orientation were such that it would take a manifold larger sample with divergent responses to upset the findings. Th1s 18 probably true with respect to other factors less related to tradition or modernity. Most of the difference in rankings are accounted for by two occupations, lawyer and used car salesman. W1th the homogenelty shown over sex, age, marital status, place of b1rth, and other traits both measured and unmeasured, a good first approximation in that similar homogenelty will be found in the larger population.

The non-rankers may have been reluctant to judge people or refused to go along with the system of rankIng occupations.

The differences in varlations reflected some interesting tra1ts. In two instances, two respondents ranked 56 of the 79 occupations as zero; in another 35 were ranked as zero. Three respondents ranked the majority of the occupations as 50:45, 26, and 60 respectively. One person ranked 45 of the occupations only in the 60's. Fourteen people would not rank below a certain flgure: two ranked thelr lowest occupation 
at 30 , two ranked their lowest at $40,81 \times$ at 50 , three at 60 and one at 70. One ranked all the occupations 88100 and another ranked them only 90 or 100. Four people left : sendfloant portions of their rankinge blank: two left 18 blank, one had 45 and one left 51 blank. One had markings of only 0,50 , or 100. This 1s striking as they took the instructions quite ilterally - glving no variations although instructions were to the contrary. One person ranked occupations as varlations of 70,68 being the lowest and 75 beling the blghest.

The Implications for soclety and research are most interesting. Our study shows that a significant portion of respondents did not follow the system of ranking occupations as usually concelved or prescribed. It was found that it was the younger that tended to be deviant. What would happen if we had a statusless soclety? Think of how it would affect relationships such as parental amb1tion and chlldhood aspiration, the marital relationship, and that of employer and employee. What would it do to our whole concept of ambition, occupational aspiration, education, author1ty, and financial security? Though our study cannot speak for all peoples, it does speak to some portion who might reflect a signiflcant trend in the thinking about occupations and status or prestige. 
The design of the questionnaire is another limitation to be considered. In further studies, the questions need to be more specific and different1ating. Also in the questionnalre, a definition was not given for "traditional Chinese values," thus different respondents might have had different interpretations of the terms. The researchers may have been misled by some of the respondents' answers to these questions. The questionnalre as a method of obtalning a sample may not have been the most effective method in that the low response rate may have in part been due to the fact that some people in the sample could nelther read nor write in ChInese and/or English. The use of Interviewing may have alleviated this difflculty. When the questionnalre was translated from 1ts English version to the Chinese version, some of the Chinese words might have carried a slightly different meaning from English words. Thus the two versions might have had undetected discrepancies in meanings. A positive quality of the questionnalre is that the answers of respondents remain anonymous and confidential and thus respondents may have felt freer In answering as compared to interviewing. The Nees found that with Chinese in San Franc1sco Chinatown, informal interviews which were like openended convelsations seemed to bring richer partiolpaticn 
and involved a full range of responses. 4 But studies show that good questionnalres give fully adequate responses and more precision.

Th1s study, though descriptive in nature and having limitations, has contributed toward better understanding of the Chinese community in relation. to Traditional/Modern att1tudes and occupational ranking, for soctal work as a profession, and for other interested and concerned persons.

\section{Recommendat1ons}

Looking bey and the stat1stical analys1s, there are a few tentative generalizations which might be made for purposes of professional practice.

1. Chinese should not be stereotyped with respect elther to their 11 fe styles, levels, or attitudes and opinions. W1thin the categories there were many Individual differences and patterns. The older Chinese and the schooled Chinese are not far removed from the younger and Chinese are not much different from the rest of Americans in traits measured. Further research must be done on the Impact of Chinese culture or what 1 means to be Chinese or American. Further study needs to be done before we can attribute opInlons, att1tudes, or behavior to being Chinese. Chinese have a full 
range of responses and comments. D1screpancy between occupationsl aspiration and occupational opportunities are probably an Individual matter and not characteristio of the population under study.

2. One set of respondents, 10 percent of the returns took the position that all occupations were of the same value, though approprlate for different persons. These were included in the hlerarchical analys18.

3. The aspirations of Chinese reflected in our sample, for their chlldren are probably such that the ch1ldren will not suffer as an ethnic trait. Case rork methods are appropriate for possible ind1vidual cases of inadequate or inappropriate ambition, but no common problem was found. 
CHAPTER NOTES

$1_{\text {Stanley Sue and Derald Wing Sue, "Chlnese- }}$ American Personality and Mental Health, "AslanAmerican Psyschological Perspectives, Sclence and Behav1 our Books, Inc., Ben Lomond, Ca., 1973; p. 122 .

I Ib1d., p. 123

3victor G. and Bret de Bary Nee, Longt1me Callforn', Pantheon Books, New York, $1972, P_{0} \times v$. I Ib1d.: p. x1r. 


\section{APPENDIX}


For each question, please " $x$ " the response which mostly matches your own, or, where indicated, 11.21 in the blank with your answer.

1. Relationship to head of household:

Head of house:

Other (Please specify)

2. Occupation Sex Age Marital status Number of dependents

3. Total income for household for last flscal year (1972). Th1s is income before taxes. (Check)

$$
\begin{aligned}
0-\$ 1,999 & \cdots \\
\$ 2,000-\$ 4,999 & \begin{array}{l}
\$ 15,000-\$ 19,999 \\
\$ 20,000-\$ 25,999
\end{array} \\
\$ 5,000-\$ 9,999 & \begin{array}{l}
\text { If over } \$ 26,000, \text { please } \\
\text { state approximate Income }
\end{array} \\
\$ 10,000-\$ 14,999 &
\end{aligned}
$$

4. The country of my birth 18

China (1ncludes malnland Chlna, Taiwan, Macao, and Hong Kong area)

U.S.A. (Includes any U. S. territory) Other (please specify)

5. In what country or countries did you at tend school during: flrst 5 years of achooling second 5 years of schooling. 
third 5 years of $8 \mathrm{chooling}$

fourth 5 years of schooling

6. Vocational or educational level: (Please check nearest completed)

arade school

Postgraduate

H1gh $8 \mathrm{chool}$ Masters

Some college Doctorate

College graduation Other: (Please spec1fy)

7. What Chinese dialects do you speak? (Check)

$$
\text { None Somewhat well Average Well }
$$

Mandarin

Cant onese

Other

Others ( $P$ lease specify)

8. What languages do you read? (Check)

Chinese

Engl1sh

Others (Please spec1fy)

9. What languages do you write? (Check)

Chinese

Engl1sh

Others (Please specify)

10. Do you think Chinese young people should learn the Ch1nese language? Yes__ No___ Not sure __ 
11. In a typical week do you eat: Western D1shes: Chinese D1shes: often sometimes seldom Chinese Dishos: orten sometimes seldom

12. What feelings do you usually have about traditlonal Chinese values: HIgh Iy sympathet10 Unsympathet1c Sympathet1c. H1ghly unsympathet1c Neutral Mixed

13. I have an active membersh1p in a Tong or other Chinese association: Yes No

14. Would you go to a Chinese herbalist:

Yes No Perhaps

15. I an a Buddh1st, Tao1st, or Confucian Protestant Cathol1c other

16. I celebrate Chinese New Year's Day: Yes No

17. I celebrate ChInese Independence Day: Yes No

18. The head of the house should be: (Check) father grandparents mother other

father \&other together 
19. I would obey my parent's wishes regarding: Cholce of schooling: Yes No___ Depends Cholce of career: Yes__ No__ Depends Cholce of mate: Yes__ No___ Depends

20. Chinese boys should be encouraged to go to college more than Chinese girls:

Strongly agree Agree Neutral

D1sagree
Strongly Disagree
Mixed

21. If you only had one boy and one girl and could send only one child to school, which would you send? Boy__ O1rl

22. Chinese should date: (Please check all that app Iy)

Chinese
(also) Orientals
Wh1tes

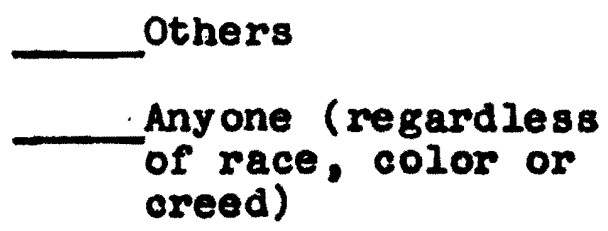

23. ChInese should not date: (Check all that apply) Chinese Other Orlentals Wh1tes Others (P lease speolfy) 
24. Chlnese should marry: (Cheok all that apply)

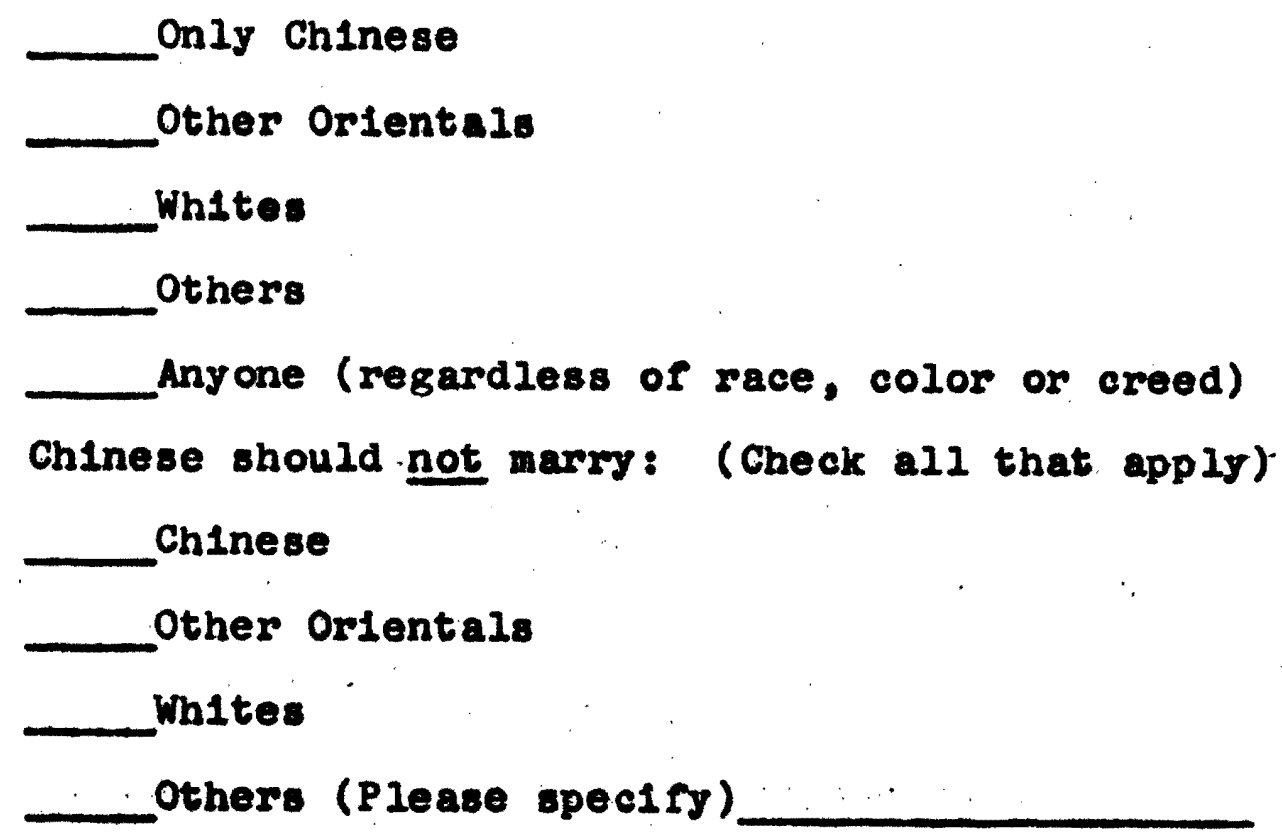


Listed below are various occupations. Please show how you regard each of these occupations (not part1cular people in them) by placing any number from 0 to 100 in the space beside that occupation. Let 0 stand for no respect whatsoever; let 50 stand for middle or average, and let 100 be the very highest any could be. Other numbers are in between. If you change your mind, please draw a line through your first answer and put a new number to the left.

Example: 72 alrplane mechanic

A person who rated this occupation as " 72 " might think that the pay is better than that of an auto mechanic, it takes considerable training but average education, a person with equal skill or intelilgence might become a dentist and make much more money; the work of a mechanic 1s dirty, or there may be a number of other thoughts.

- accountant

- factory owner. building contractor car salesman Insurance salesman. show owner general manager or department store-

banker sales person mechanic carpenter repalrman barber/beauty operat or farmer tallor upholsterer pharmac1st nurse doct or medical technician nurse's alde dietitian hospltal ward clerk dental hygien1st c1ty councilman c1vil engineer publ1c prosecutor meter mald highway construction worker 


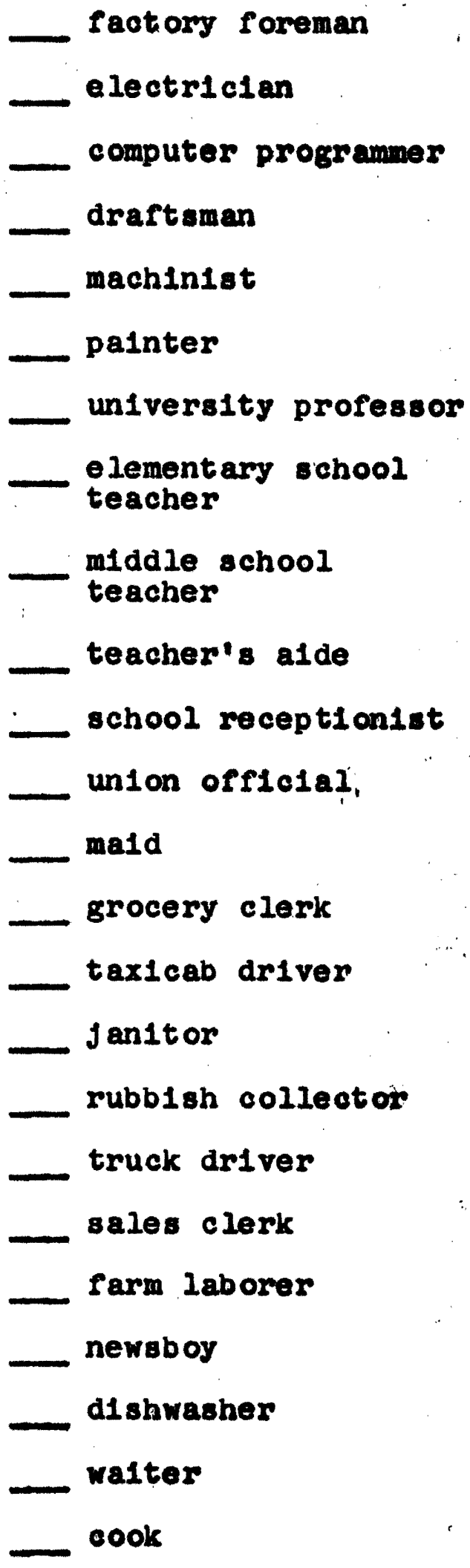

ma1 Iman

executive secretary

bank teller

typ1st

f11e clerk

bookkeeper/cash1ex

social worker

psycholog1st

lawyer

pol1ceman

fireman

Juvenile court

counse 1 or

recreation director

social security

counselor

author

actor

fashion designer

minister

nun

m1s81onary

priest

gas Btation attendant

bus driver

housekeeper 

parking at tendant 